\title{
Focal therapies for the treatment of localized prostate cancer: The role of irreversible electroporation - Present or future?
}

\author{
Pedro Conceição Fernandes ${ }^{a}$, Bruno Jorge Pereira ${ }^{a, b, *}$ \\ a Faculdade de Ciências da Saúde, Universidade da Beira Interior, Covilhã, Portugal \\ b Serviço de Urologia, Hospital Pêro da Covilhã, Centro Hospitalar Cova da Beira, EPE, Covilhã, Portugal
}

Received 27 June 2015; accepted 10 October 2016

Available online 2 November 2016

\section{KEYWORDS \\ Prostate cancer; \\ Focal therapy; \\ Focal treatment; \\ Electroporation}

\begin{abstract}
In the PSA era, the incidence of localized prostate cancer has been increasing. This reality requires new therapeutic strategies, in order to give an answer to patients, in whom active surveillance may be indicate but desire more interventionist strategy with minimal side effects and without compromising cancer control. In these cases, focal therapies that include irreversible electroporation may be effective alternative strategies. The irreversible electroporation is an emergent approach on focal treatment of localized $\mathrm{PCa}$. The nonthermal mechanism that preserves the tissue architecture without damaging tissue structures, such as vessels and nerves within the target region, is the main advantage comparatively to other techniques used in focal treatment. The number of clinical studies is reduced and the results still immature. (c) 2016 Associação Portuguesa de Urologia. Published by Elsevier España, S.L.U. This is an open access article under the CC BY-NC-ND license (http: / / creativecommons.org/licenses/by-nc-nd/ $4.0 /)$.
\end{abstract}

Terapêuticas focais no tratamento do carcinoma da próstata localizado: o papel da eletroporação irreversível - presente ou futuro?

Resumo Na era do PSA, a incidência do carcinoma da próstata localizado tem vindo a aumentar. Esta realidade exige novas estratégias terapêuticas, a fim de poder dar uma resposta aos pacientes, os quais, embora esteja indicada a vigilância ativa, desejam uma estratégia mais interventiva com poucos efeitos adversos e sem compromisso do controlo da doença.

\footnotetext{
* Corresponding author.

E-mail address: brunoalexpereira@gmail.com (B.J. Pereira).
} 
Nestes casos, as terapêuticas focais, que incluem a eletroporação irreversível, podem ser uma estratégia alternativa efetiva. A eletroporação irreversível constitui uma abordagem emergente no tratamento do carcinoma da próstata localizado. 0 mecanismo de lesão celular não-térmico que preserva a arquitetura tecidular sem lesão de estruturas, tais como vasos e nervos dentro da região alvo, constitui a principal vantagem comparativamente com as outras técnicas utilizadas no tratamento focal. 0 número de estudos clínicos é reduzido e os resultados ainda são imaturos.

(c) 2016 Associação Portuguesa de Urologia. Publicado por Elsevier España, S.L.U. Este é um artigo Open Access sob uma licença CC BY-NC-ND (http://creativecommons.org/licenses/bync-nd/4.0/).

\section{Introduction}

In industrialized countries, the prostate cancer (PCa) is the most common cancer among men over 50 years. ${ }^{1}$ The incidence is highest in Northern and Western Europe (>200/100,000), while rates in Eastern and Southern Europe have showed a continuous increase and appear to be reaching the levels seen in Northern and Western Europe. ${ }^{2}$ Although the incidence has increased in all parts of Europe, this phenomenon is most notable in Northern Europe and in the youngest group (35-64 years). ${ }^{2}$

PCa is currently diagnosed in $15-20 \%$ of men during their lifetime, but the lifetime risk of death from PCa is only $3 \% .^{3}$ The mortality attributable to this pathology tends to range widely from country to country in the industrialized world. ${ }^{3}$ In most Western countries, mortality rates due to PCa have been decreasing, with varying rates across the different nations. ${ }^{4}$ In Europe, during last decade, the 5-year relative survival percentages for prostate cancer steadily increased from $73.4 \%$ in $1999-2001$ to $83.4 \%$ in $2005-2007$, despite having identified discrepancies between countries of Eastern Europe and the rest of Europe. ${ }^{5}$ Likewise, the United States of America has recorded a similar trend in mortality, condition for which aggressive PCa screening policy has had a preponderant role. ${ }^{4}$

Currently, PCa screening using PSA has contributed to the increasing the number of cases diagnosed at an earlier stage. Together with the improvement of imaging techniques and biopsy, ${ }^{1}$ the incidence of localized, small volume and low grade PCa has increased substantially. ${ }^{6}$ In these cases, active surveillance appears to be a feasible management strategy in carefully selected patients. However, $18 \%$ of men on active surveillance choose a radical approach due to anxiety. ${ }^{3}$ On the other hand, despite technological progress in surgery and radiotherapy, the occurrence of side effects remains considerably high. ${ }^{6}$

Although in experimental phase, focal therapy using the most diverse techniques has gained preponderance by minimizing damages on the remaining gland and surrounding structures, while retaining the therapeutic benefits ${ }^{6}$ and without commitment of the life expectancy. ${ }^{7}$ This strategy is an approach similar to that already done in the treatment of solid-organ malignancies, such renal, thyroid, breast, liver and pancreas. ${ }^{6}$
There is evidence that the natural history of the disease is mainly driven by a lesion of large size and high grade called index lesion, ${ }^{6}$ justifying this approach.

The high intensity focused ultrasound (HIFU) and cryotherapy are the most studied techniques. Others, such as photothermal laser, photodynamic therapy and focal brachytherapy, have been studied as plausible approaches to partial ablation of the prostate gland. Recently, irreversible electroporation (IE) appears to be a technique with enough potential to focal treatment of PCa.

\section{Materials and methods}

A literature search was done on PubMed and ScienceDirect databases using the keywords "prostate cancer", "prostatic neoplasms", "focal treatment", "focal therapy", "irreversible electroporation". The articles included were published between 01/01/2004 and 31/12/2014. Original articles, review articles and clinical trials conducted in humans were included. In each study, the following data were extracted: characteristics of target population, disease control outcomes, side effects and preservation of urinary continence and erectile function after treatment.

\section{Irreversible electroporation}

\section{Principles and clinical applicability}

The IE, used in the food industry for sterilization, emerged as a new method for minimally invasive tumour ablation. ${ }^{8}$ The bases that have contributed to this evolution naturally derived of reversible electroporation, which has been used mainly as a research tool in the medical field to promote the transmembrane transport of genes, antibodies, RNA, DNA, and even drugs (e.g.: cytostatics). ${ }^{8-10}$ Then, an electrical field that transiently increases the porosity of the membrane facilitates the exchange of substances. ${ }^{8}$ In contrast, in IE an electrical field of much higher voltage is applied, which leads to permanent nanopore formation in the cell membrane, with disruption of cellular homeostasis and, consequently, cell death by apoptosis. $8,9,11,12$ The dead cells are removed by the immune system and replaced through mechanisms of innate cellular regeneration. The preservation of the surrounding tissue architecture allows fast activation 
of the immune system and consequent elimination of dead cells, but also tissue regeneration, avoiding scar formation. ${ }^{8}$ However, if the energy applied is high enough to induce thermal damage, it can cause denaturation of proteins and collagen and, ultimately, tissue necrosis. ${ }^{12}$

A single bipolar electrode or multiple unipolar electrodes placed and activated in pairs are necessary requirements for technical implementation. Owing to the relatively small size of each ablation zone, multiple electrodes are required. ${ }^{8}$ The magnitude of the electric field, necessary to achieve the therapeutic effect, is influenced by spacing and relative positions of the several electrodes ${ }^{8}$ and by the duration and interval between the electric pulses. ${ }^{12}$ Furthermore, the size of cells and tissue density are variables to take in account. $^{10}$

During the ablation procedure, strictly defined areas are formed, thus allowing an immediate monitoring of the area treated by MRI and ultrasound. ${ }^{11}$

The presence of intense muscle contractions, caused by the high-voltage electrical pulses, requires general anaesthesia with complete neuromuscular blockade. ${ }^{8}$ Nevertheless, the presence of small muscle contractions obliges for a constant check in the location of electrodes, ${ }^{8}$ in order to avoid injuries to healthy structures. ${ }^{1,13}$ A close monitoring of the cardiac rhythm and synchronization of the IE pulses with ECG is also mandatory. Although arrhythmias are rare, they can lead to haemodynamic disturbance, hence the need for an invasive monitoring of the blood pressure. ${ }^{8}$

IE is not limited by the disadvantages of the heating or cooling techniques and could virtually overcome some of the deficiencies inherent to those techniques. ${ }^{8,9}$ The results of preclinical and clinical studies published makes this technique a potential very reasonable option for the treatment of a large variety of tumours, including periportal liver masses, pancreatic cancer, perihilar renal tumours, PCa and other soft tissue tumours. ${ }^{8}$

The indications and contraindications are not fully known. The inability to destroy large volume of tissue constitutes a major limitation of this technique, a problem that could eventually be suppressed by the use of multiple probes $^{8,9}$ or by the addition of chemotherapeutic or cytotoxic agents, ${ }^{9}$ in spite of increasing the complexity of the procedure. Similarly, inaccessible lesions cannot be treated by this way. ${ }^{8}$ This procedure is contraindicated in patients with cardiac arrhythmias or any condition that promotes their development (e.g.: electrolyte disorders), as well as those who cannot be subjected to general anaesthesia. ${ }^{8}$

Given the particularities described herein, this technique may be an acceptable alternative in the primary treatment of PCa. ${ }^{12}$

\section{Clinical outcomes}

The clinical experience of IE on PCa in humans is scarce.

The first study, published by Brausi et al. ${ }^{14}$ in 2011, revealed the provisional results related to application of IE in 11 men with mean age of 70.2 years. All men had low risk disease - 10 were staged with T1C and 1 was staged with T2a. The preoperative mean value of PSA was $6.43 \mathrm{ng} / \mathrm{mL}$. There were no reported complications. The study stated a follow-up around 19 months, with PSA determination and monitoring of urinary symptoms (IPSS) and erectile function (IIEF) at 14th, 30th, 90th and 525th day. Only 1 patient had acute urinary retention, while 3 patients had transient urge incontinence. The mean PSA values were $3.5 \mathrm{ng} / \mathrm{mL}$; $2.9 \mathrm{ng} / \mathrm{mL} ; 3.3 \mathrm{ng} / \mathrm{mL}$; and $3.12 \mathrm{ng} / \mathrm{mL}$. The continence rate was $100 \%$. IPSS was reduced to $7.72 ; 7 ; 6.12 ; 4.28$ and 4 respectively, while IIEF was $13.18 ; 10.45 ; 10.5 ; 11$ and 17.3 . Biopsies made 30 days after El were negative in 8 (73\%) patients. Three patients $(27 \%)$ had persistent adenocarcinoma.

In 2013, Dickinson et al. ${ }^{15}$ published a study of 15 men with low (7\%), medium (80\%) and high (13\%) risk disease that received focal IE between August 2011 and September 2012. IE was received as primary treatment in 9 men and as a salvage procedure in 6 . Mean age was 65 years and mean PSA was $5.9 \mathrm{ng} / \mathrm{mL}$. During the procedure there were no complications. Four men (27\%) had grade 1 and 3 had grade 2 postoperative adverse events. There were no severe adverse events. Continence and erectile function were preserved in all patients with available data.

Valerio et al. ${ }^{16}$ presented in 2014 a pilot study where the toxicity profile of IE in the focal treatment of PCa was measured. This was a retrospective multicenter study that included 34 men with low (26\%), intermediate (71\%) and high (3\%) risk disease. In this analysis, all patients received El as primary treatment. The mean age was 65 years and the mean PSA was $6.1 \mathrm{ng} / \mathrm{mL}$. There were no cases of severe toxicity during the 6 months of follow-up. Twelve (35\%) and 10 (29\%) patients had grade 1 and 2 complications, respectively. Six (18\%) patients had debris and/or haematuria and $5(15 \%)$ had dysuria. Five patients developed uncomplicated urinary tract infection and only 2 patients had urinary retention. In 4 men did not occur genito-urinary adverse events. In the follow-up period, mpMRI show suspicious residual disease in 6 patients, of whom 2 remain on surveillance. Secondary local treatment was needed in 4 (12\%) men. From functional view, $100 \%(24 / 24)$ patients were continent and potency was preserved in 95\% (19/20). According to these authors, prostate posterior tumours close to the rectum may be a contraindication to electroporation given its potential increased risk for rectal lesions.

\section{Discussion}

The concept of focal therapy is still controversial. To some researchers this approach includes only the focus treatment, ${ }^{17}$ to others, any approach able to preserve part of prostatic tissue (e.g.: "hockey stick" ablation, hemiablation and focal ablation) maybe considered focal therapy. ${ }^{6}$ Apart from these considerations, focal therapies are emerging treatment modalities for localized PCa.

In PSA's era, the number of new PCa diagnosed at early stage has become a reality. In men with low risk disease, European Urology Association accepts active surveillance (level of evidence $2 a$, grade of recommendation A). ${ }^{3}$ However, focal therapies are alternatives to active surveillance among anxious patients who request active treatment. ${ }^{18}$ Currently, the radical approach, such as radical prostatectomy, external radiotherapy or brachytherapy, is the gold standard for the treatment of PCa. The considerable morbidity of such strategies, which translates into erectile 
dysfunction, incontinence and rectal toxicity (50\%, $10 \%$ and $10 \%$, respectively), ${ }^{1}$ fostered the growing interest of the scientific community around focal therapies. ${ }^{6}$ These permit to destroy the tumour and sparing healthy surrounding tissues such as neurovascular bundles and external urinary sphincter and achieve the coveted Trifecta Outcome (padfree continence, erections sufficient for penetration with or without oral PDE5-I and disease control). ${ }^{6}$

The index lesion, which is generally defined as the largest volume lesion with higher grade, is the target of any focal therapy. It is postulated that selective destruction of this lesion prevents cancer progression. ${ }^{18}$ Evaluation of biological behaviour of any lesion through its volume is a poor strategy, even that lesions with small size have better prognosis. ${ }^{19}$ Although PCa is a multifocal disease, multiple small foci may represent clinically insignificant disease that are unlikely to progress and impact on quality of life. ${ }^{19}$ Surprisingly, the study of Haffner et al. ${ }^{20}$ prove that the lethal clone comes from small and low grade focus in the primary tumour.

Proper identification of ideal patient for focal therapy is undoubtedly one of the greatest challenges. ${ }^{19}$ The localization and characterization through biopsy and imaging techniques is the foundation of the whole process. Prostate biopsy guided by TRUS is the modality most used in the diagnosis of $\mathrm{PCa}$, although the same cannot predict the extent of the tumour on final pathological specimen. ${ }^{19,21}$ Even saturation biopsies fail when a more detailed characterization of extent of the disease is desired. ${ }^{19,21}$ The template prostate mapping biopsy (TPMB) is widely accepted by various consensus groups and with proven value in several studies. ${ }^{19,21}$ Recent data have shown that multiparametic MRI is able to detect clinically significant, high-grade tumours with high accuracy when using TPMB as the reference standard. ${ }^{19}$

There are no standardized criteria to define persistence or progression of the cancer. ${ }^{18}$ Although measurement of PSA is recommended during follow-up, the role of this biomarker is not established due to the lack of consensus about the definition of biochemical recurrence. ${ }^{6,19,22}$ In studies reported there were no established criteria to define biochemical recurrence.

Until now there is no consensus about the definition of disease control. The existence of higher Gleason grade cancer, the persistence of cancer with similar or lower grade after repeat focal therapy in the same area or the need for additional PCa treatment other than focal therapy is defined as therapeutic failure by the International Multidisciplinary on Trial Design. ${ }^{23}$ In the reported studies only reference was made to the number of individuals with positive biopsy.

A presumed but unproven advantage of focal therapy is the lower likelihood and severity of treatment related morbidity. ${ }^{19}$ Although the number of subjects in each study is reduced, the main complications reported were transient urge incontinence, persistent debris hematuria and acute urinary retention. In the available studies of Brausi et al. , ${ }^{14}$ Dickinson et al. ${ }^{15}$ and Valerio et al. ${ }^{16}$ all men remained continent after treatment. Similarly, erectile function remained unchanged in 2 studies. ${ }^{14,15}$ Noteworthy, at study of Brausi et al. ${ }^{14}$ IIEF-5 score before treatment was 16.8 and at the last assessment was 17.3. At study of Valerio et al. ${ }^{16}$ the erectile function was preserved in $95 \%$ of patients.
The knowledge about the clinical application of IE in the treatment of PCa is very limited, which does not allow confirming whether this provides equally convincing outcomes as those obtained in the more studied techniques such as HIFU and cryotherapy. This approach seems to have some advantages over the other techniques. In thermal ablation, tissue heating or freezing frequently correlates with devastating complications in adjacent vital organs, such as bowel, ductal structures and critical vascular supply. In theory, these disadvantages maybe avoided in IE owing to its nonthermic mechanism that preserves the tissue architecture without damaging surrounding structures, vessels and nerves. ${ }^{8,9}$

On the other hand, the safety and efficacy profiles of the IE are still largely unknown. ${ }^{8}$ Furthermore, this approach does not allow the destruction of large volumes of tissue under a safe electric field. ${ }^{8,9}$ People without intact immune system may benefit less from this approach. ${ }^{11}$

\section{Conclusion}

IE stays in its infancy in the focal treatment of PCa. Currently, the experience is very limited and follow-up is immature. In the future, more robust studies will be required to enable a comparison with other techniques used in focal treatment of localized PCa as well as traditional approaches.

\section{Conflicts of interest}

The authors have no conflicts of interest to declare.

\section{References}

1. Bozzini G, Colin P, Nevoux P, Villers A, Mordon S, Betrouni N. Focal therapy of prostate cancer: energies and procedures. Urol Oncol: Semin Orig Investig. 2013;31:155-67.

2. Arnold M, Karim-Kos HE, Coebergh JW, Byrnes G, Antilla A, Ferlay J, et al. Recent trends in incidence of five common cancers in 26 European countries since 1988: analysis of the European Cancer Observatory. Eur J Cancer (Oxford, England: 1990). 2013.

3. Mottet N, Bastian PJ, Bellmunt J, van den Bergh RCN, Bolla $\mathrm{M}$, van Casteren NJ, et al. Guidelines on prostate cancer. In: European Association of Urology Guidelines - 2014 [Internet]. Arnhem, The Netherlands: European Association of Urology; 2014. Available from: http://www.uroweb.org/guidelines/

4. Etzioni R, Gulati R, Cooperberg MR, Penson DM, Weiss NS, Thompson IM. Limitations of basing screening policies on screening trials: the US preventive services task force and prostate cancer screening. Med Care. 2013;51:295-300.

5. De Angelis R, Sant M, Coleman MP, Francisci S, Baili P, Pierannunzio D, et al. Cancer survival in Europe 1999-2007 by country and age: results of EUROCARE-5 - a population-based study. Lancet Oncol. 2014; 15:23-34.

6. Valerio M, Ahmed HU, Emberton M, Lawrentschuk N, Lazzeri M, Montironi R, et al. The role of focal therapy in the management of localised prostate cancer: a systematic review. Eur Urol. 2014;66:732-51.

7. Bostwick DG, Waters DJ, Farley ER, Meiers I, Rukstalis D, Cavanaugh WA, et al. Group consensus reports from the Consensus Conference on Focal Treatment of Prostatic Carcinoma, Celebration, Florida, February 24, 2006. Urology. 2007;70 Suppl.:42-4. 
8. Lu DS, Kee ST, Lee EW. Irreversible electroporation: ready for prime time? Tech Vasc Interv Radiol. 2013;16:277-86.

9. Jiang C, Qin Z, Bischof J. Membrane-targeting approaches for enhanced cancer cell destruction with irreversible electroporation. Ann Biomed Eng. 2014;42:193-204.

10. Canatella PJ, Black MM, Bonnichsen DM, McKenna C, Prausnitz MR. Tissue electroporation: quantification and analysis of heterogeneous transport in multicellular environments. Biophys $\mathrm{J}$. 2004;86:3260-8.

11. Kim H-B, Sung C-K, Baik KY, Moon K-W, Kim H-S, Yi J-H, et al. Changes of apoptosis in tumor tissues with time after irreversible electroporation. Biochem Biophys Res Commun. 2013;435:651-6.

12. Rubinsky J, Onik G, Mikus P, Rubinsky B. Optimal parameters for the destruction of prostate cancer using irreversible electroporation. J Urol. 2008;180:2668-74.

13. Marien A, Gill I, Ukimura O, Betrouni N, Villers A. Target ablation-image-guided therapy in prostate cancer. Urol Oncol. 2014;32:912-23.

14. Brausi MA, Giliberto GL, Simonini GL, Botticelli L, Di Gregorio C. Irreversible Electroporation (IRE), a Novel Technique for Focal Ablation of Prostate Cancer (PCA): results of a interim pilot study in low risk patients with PCA. Eur Urol Suppl. 2011;10:300.

15. Dickinson CL, Valerio M, Ahmed HU, Freeman A, Allen C, Emberton $M$. Early clinical experience of focal therapy for localised prostate cancer using irreversible electroporation. Eur Urol Suppl. 2013;12:e584.
16. Valerio M, Stricker PD, Ahmed HU, Dickinson L, Ponsky L, Shnier R, et al. Initial assessment of safety and clinical feasibility of irreversible electroporation in the focal treatment of prostate cancer. Prostate Cancer Prostatic Dis. 2014;17: 343-7.

17. Hale Z, Miyake M, Palacios DA, Rosser CJ. Focal cryosurgical ablation of the prostate: a single institute's perspective. BMC Urol. 2013;13:2.

18. Giannarini G, Gandaglia G, Montorsi F, Briganti A. Will focal therapy remain only an attractive illusion for the primary treatment of prostate cancer? J Clin Oncol. 2014;32:1299-301.

19. Mearini L, Porena M. Pros and cons of focal therapy for localised prostate cancer. Prostate Cancer. 2011:2011.

20. Haffner MC, Mosbruger T, Esopi DM, Fedor H, Heaphy CM, Walker DA, et al. Tracking the clonal origin of lethal prostate cancer. J Clin Investig. 2013;123:4918-22.

21. de la Rosette J, Ahmed H, Barentsz J, Johansen TB, Brausi M, Emberton M, et al. Focal therapy in prostate cancer-report from a consensus panel. J Endourol. 2010;24:775-80.

22. Muller BG, van den Bos W, Brausi M, Futterer JJ, Ghai S, Pinto PA, et al. Follow-up modalities in focal therapy for prostate cancer: results from a Delphi consensus project. World J Urol. 2015.

23. van den Bos W, Muller BG, Ahmed H, Bangma CH, Barret E, Crouzet $S$, et al. Focal therapy in prostate cancer: international multidisciplinary consensus on trial design. Eur Urol. 2014;65:1078-83. 